Portland State University

PDXScholar

$11-2016$

\title{
Nesting Microhabitat Use by a Ground-nesting Songbird: Strict Preferences or Random Choice?
}

Jazzmine Allen

Portland State University

Follow this and additional works at: https://pdxscholar.library.pdx.edu/honorstheses

Let us know how access to this document benefits you.

\section{Recommended Citation}

Allen, Jazzmine, "Nesting Microhabitat Use by a Ground-nesting Songbird: Strict Preferences or Random Choice?" (2016). University Honors Theses. Paper 348.

https://doi.org/10.15760/honors.337

This Thesis is brought to you for free and open access. It has been accepted for inclusion in University Honors Theses by an authorized administrator of PDXScholar. Please contact us if we can make this document more accessible: pdxscholar@pdx.edu. 
Nesting Microhabitat Use by a Ground-nesting Songbird:

Strict Preferences or Random Choice?

by

Jazzmine Allen

An undergraduate honors thesis submitted in partial fulfillment of the requirements for the degree of

Bachelor of Science

in

University Honors

and

Organismal Biology

Thesis Adviser

Dr. Michael T. Murphy

Portland State University

2016 


\begin{abstract}
Nest site choice of birds has the potential to affect predation rates on nests and reproductive success for many bird species, and is thus tied closely to fitness. Vegetation at a particular site influences concealment (and predation rate as a result). Research has shown that birds of various species base nest site choice on variables like nest height, and especially vegetation cover within the microhabitat around a site. I studied nest site choice in ground-nesting birds, which tend to experience high predation rates near the nest site, and therefore might be expected to be particular choosy about vegetation near the nest. I used Spotted Towhees (Pipilo maculatus) nesting in Lesser Park in Portland, OR, as a model species for ground-nesting birds. I compared Spotted Towhees nest sites $(n=15)$ to both randomly-chosen sites within $10 \mathrm{~m}$ of the nests $(\mathrm{n}=$ 15; random territory sites) and other randomly-chosen locations throughout the park $(\mathrm{n}=25$; random park locations) to test whether vegetation structure and floristic composition differed. I measured (1) vegetation height and density near the nest, (2) size and spacing of trees around nests, and (3) floristic composition of vegetation near nests. I found that nest sites and both categories of random sites had dense and equal amounts of vegetation near ground level (0-20 $\mathrm{cm}$ above ground), but that nest sites had more vegetation between $21-40 \mathrm{~cm}$ and $61-100 \mathrm{~cm}$ above ground than random locations. However, there was no evidence that the structure of the tree community or species composition differed between nest sites and random locations. Towhees thus appear to prefer to place nests in locations with greater vertical cover directly over the nest.
\end{abstract}




\section{Introduction}

Nest site choice can be a crucial factor in determining the reproductive success of birds (Clark et al. 1983, Holway 1991, Pleszczynska 1978). Nest site suitability is thought to be affected primarily by microclimate and predation risk (Holway 1991). Predation risk is critical because predation is the main source of nest loss in most bird species, accounting for an average of about $80 \%$ of nest failures (Martin 1993b). Vegetation in the microhabitat around the nest is therefore important because of its potential to influence the likelihood that a predator will locate a nest. For example, vegetation density around the nest (and therefore nest concealment) has been found to influence predation rates (Martin \& Roper 1988, Borgman \& Conway 2015, Schill \& Yahner 2009). Vegetation can be particularly important for ground-nesting birds, as they tend to have especially high predation risk (Ricklefs 1969, Solis \& De Lope 1995; but see Martin 1993a). Ground-nesting birds are particularly poorly represented in urban habitats (Hedblom and Söderström 2010) and a possible explanation may be that inadequate vegetation cover at ground level precludes successful nesting.

The floristic composition of vegetation may also be an important determinant of nest site choice. For instance, Martin \& Roper (1988) showed that nest success of Hermit Thrushes (Catharus guttatus) was highest for nests placed in and when surrounded by small white fir (Abies concolor) trees than when surrounded by trees of other species. The presence of native or nonnative vegetation species can also influence site choice. Birds may be drawn to exotic species if their leaves emerge earlier in spring (Schmidt \&Whelan 1999, Remeš 2009) or if branch architecture facilitates nest placement (Schmidt \& Whelan 1999). However, success is often lower for nests placed on or near exotic vegetation (Schmidt \&Whelan 1999, Borgmann \& 
Roldewald 2004, Lloyd \& Martin 2005, Remeš 2009). The reasons are varied, but lower nest height (Borgmann \& Rodewald 2004) and absence of thorns on some exotic species (Schmidt \&Whelan 1999) have been suggested as explanations.

Spotted Towhees (Pipilo maculatus, hereafter referred to as towhees) are a common species of ground-nesting passerine. Like many ground-nesting species, predation is the main source of nest mortality (Small 2005), and nest concealment is an important factor influencing nest predation risk. This makes it likely that vegetation in the nest microhabitat should be an important factor influencing choice of nest sites by female towhees. However, it is not clear that towhees exhibit active choice of nest sites or instead select a territory within which they randomly place their nests (Bartos Smith \& Greenlaw 2015).

Here I describe the physical and floristic structure of nest sites used by towhee in an urban park in Portland, OR, USA to evaluate whether active nest site choice occurs. I compared nest site microhabitats to the microhabitats of random sites located in the same territory within $10 \mathrm{~m}$ of the nest and to other random sites throughout the study area in an attempt to identify vegetation-related factors that might influence towhee nest site choices. I included both structural and floristic aspects of nest microhabitat, and in particular, examine the potential importance of exotic plants on nest site choice. English holly (Ilex aquifolium), English ivy (Hedera helix) and Himalayan blackberry (Rubus armeniacus) are particularly pernicious invasive plants in Portland's parks, including the park in which I conducted my research. My goals were thus to (1) quantify the structural nest microhabitat of towhees, (2) at a larger scale, describe the tree community in the immediate area around the nest, (3) assess the extent to which exotic vegetation occurred at nest sites, and ultimately, (4) determine if towhee nest sites, random 
territory sites, and random park sites differed in any of these traits to indicate that active choice of nest sites occurred.

At each site, I found the average vegetation density around the site, and identified the most dominant ground cover species surrounding the site. Additionally, I collected the number of contacts made with woody stems near the site. Finally, I found the Diameter at Breast Height (DBH, 1.37 meters up from the base of the tree), distance to, and species of eight nearby trees. All of these factors were used to compare nest sites to random sites near the nest, and to other random sites.

\section{Methods}

\section{Study System}

I conducted my research between July and September of 2016 at Lesser Park, located in Portland, OR. Portland is a 34,558 ha city with a population of approximately 632,309 (U.S. Census Bureau 2015). Lesser park (9 ha), located in a residential area of SW Portland, is a mixture of deciduous forest and mixed-evergreen deciduous forest ("Vegetation Unit Summaries for Lesser Park” 2009). The canopy consists mainly of 15-25 m Douglas-fir (Pseudotsuga menziesii) and big-leaf maple (Acer macrophyllum) trees. Primary native understory plants include beaked hazelnut (Corylus cornuta), vine maple (Acer circinatum) Indian-plum (Oemleria cerasiformis), and sword fern (Polystichum munitum). As noted above, invasive understory species include English ivy, English holly, and Himalayan blackberry.

Towhees are distributed from southwestern Canada through the western United States and south into parts of Mexico and southwestern Guatemala. In Oregon, they are year-round 
residents. Towhees are socially monogamous, and breed in areas with dense, shrubby undergrowth. Multi-brooded, they typically lay 3 to 4 eggs/clutch, and attempt at least two clutches per season, but can successfully raise up to three broods per season (Bartos Smith et al. 2012, Shipley et al. 2013). Two of the primary factors affecting towhee reproductive success in Portland parks include predation and food abundance (Bartos Smith et al. 2012). Predation is the main reason why over $50 \%$ of nests fail. However, nestling starvation tends to occur more often in nests found in the interior of parks and this appears to be because food is more abundant near park edges.

Lesser park and towhees were selected for this study in part because research had been conducted in this area and on this species (Smith et al. 2016, Shipley et al. 2013) and thus the system is well known. Additionally, and despite the general low abundance of ground nesting birds in urban areas (Hedblom and Söderström 2010), towhees are one of the more abundant bird species in Portland's parks and greenspaces. Towhees thus provide a very tractable system that can serve as a model for studying the ecology of ground-nesting and ground-foraging species in urban environments, an ecological group identified as one in need of further study (Chamberlain et al. 2009).

\section{Field methods}

Nest searching began in early April, 2016, and continued through early July. Towhee nests are placed on the ground and are typically difficult to find. Hence, most nests were discovered by watching females in nest building as they carried nest material back to nesting locations, while a few were detected by accidentally flushing females while they incubated eggs. 
The locations of the 15 towhee nest discovered were marked with GPS, and a small numbered flag located several meters from the nest. To quantify the microhabitat of each towhee nest site (TNS), I modified methods described initially by James (1971) and subsequently used in many studies. Primarily, this involved identification and measurement of the vegetation around each nest site (see below). I also collected identical data for a second spot (random territory site: RTS) on the same territory and located in a random direction (north, south, east or west) and distance (between 1 and $10 \mathrm{~m}$ ) from the TNS. All directions were found using a compass, and random distances and directions were generated with random number generation software (Haahr 2016). RTS were located so that no spatial overlap occurred between them and the TNSs. Finally, I also collected identical data at 25 other random locations throughout the park (random park sites: RPS), to provide a second level of comparison to TNS. Comparison of RPS to RTS also allowed an assessment of the extent to which territory sites were actively selected based on habitat features. The RPSs were generated with the ArcGIS random points tool ("ArcMap" 10.4.1).

At all 55 sites I first estimated the density of vegetation in a circular $1 \mathrm{~m}$ area centered on the nest. I used a vertical $1.0 \mathrm{~m}$ pole with horizontal poles extending $50 \mathrm{~cm}$ outward on either side of the pole at heights of 0.2, 0.4, 0.6, 0.8, and $1.0 \mathrm{~m}$ above the base. Each of the horizontal poles was divided into five equal length $10 \mathrm{~cm}$ sections. To quantify vegetation density at different heights above the nest I positioned the pole in the center of the site with the horizontal extensions in a north-south orientation. I then recorded the number of $10 \mathrm{~cm}$ sections at each height that was touched by any kind of vegetation. I then rotated the pole $60^{\circ}$ to the east, repeated the counts, and then rotated $60^{\circ}$ once more and conducted a final count at all heights. Additionally, I identified and recorded the ground vegetation types that I estimated to be the 
most common (as a percentage of the total) within the six $60^{\circ}$ sections of an imagined $5 \mathrm{~m}$ circle that surrounded each site. The dominant species was recorded for each of the six sections.

To quantify shrub level vegetation, I held a $50 \mathrm{~cm}$ stick at breast height while walking a $5 \mathrm{~m}$ transect across the site in north-south and then east-west directions with the site as the center of the transect. I recorded the number of times the stick made contact with woody stems. Woody stems included all branches/stems with a thickness $\leq 2.54 \mathrm{~cm}$. I also identified the species that the stick made contact with. Finally, for each site I also identified the species and recorded the distance to and diameter breast height (DBH) of the two closest trees to the sample point that occurred in the northeast, southeast, southwest, and northwest directions from the site. My purpose in quantifying tree community structure around points was to assess the degree to which towhees discriminated among habitats at a scale above the nest microhabitat.

\section{Analyses}

To quantify vertical structure I summed the number of $10 \mathrm{~cm}$ sections of the horizontal bar that contacted vegetation over the six measurements made at $60^{\circ}$ intervals (maximum possible $=30$ ) for all five heights above ground $(0.2,0.4,0.6,0.8$ and $1.0 \mathrm{~m})$. For purpose of analysis, I combined the totals for $0.6,0.8$ and $1.0 \mathrm{~m}$ because contacts above $0.4 \mathrm{~m}$ were uncommon and usually zero. To examine relative amounts of native and non-native ground cover at the different sites, native vegetation was combined into one category, while non-native vegetation was examined on a per-species basis. Prior to analysis all variables were examined graphically to identify potential outliers and assess the degree to which they conformed to assumptions of normality. Those exhibiting non-normal distribution were transformed as $\log [\mathrm{x}+1]$. 
I used one-way analysis of variance (ANOVA) to compare vegetation density, vegetation type, tree DBH, and distance to nearby trees among TNS, RTS, and RPS. Correlation analysis was conducted to analyze relationships between vegetative variables within sites. Organisms often respond simultaneously to multiple factors in their environment that may go undetected using univariate analyses. I therefore used principal component analysis (PCA) to describe habitat at the three types of sites. PCA takes the original data, and based upon the covariation amongst variables, creates new synthetic variables that are linear combinations of the original variables that now describes the major gradients of variation among the variables. I only used the resulting new variables (principal component 1 [PC1], PC2, etc.) when their eigenvalues were greater than 1.0. Each site receives a score on the new variables (i.e., PC1 and PC2) and I used ANOVA to again compare PC scores among TNS, RTS, and RPS.

I used Statistix ("Statistix" 2008) to conduct all analyses, and results were considered significant if $P \leq 0.05$, while results were considered marginally significant if $0.1 \geq P \geq 0.05$. Statistics are reported in the form of means \pm SE.

\section{Results}

\section{Density and size of vegetation}

Comparison of the size and density of vegetation among TNSs, RTSs, and RPS failed to detect difference in the size or spacing of trees around sample points (Table 1). Similarly, there was no difference in shrub density (i.e., horizontal contacts at breast height; Table 1) or in the density of vegetation near ground level at sites (i.e, $0.2 \mathrm{~m}$ above the nest; Table 1). However, there were differences among sites in vegetation density at a height of 0.4-m and again at between 0.6 and 
$1.0 \mathrm{~m}$ above ground (Table 1). The statistically differences were driven by the lower cover at RPSs compared to RTSs. TNS did not differ from either RTSs or RPSs.

\section{Species of vegetation}

I compared, using ANOVA, contacts made at the ground, shrub, and tree levels among site types. There was no difference in horizontal contacts at breast height within 2.5-m of the site for any of the species, except for a marginally significant difference in amount of English holly and Himalayan blackberry; TNSs tended to have more blackberry while RPSs tended to have more holly (Table 2). The potential difference in blackberry was questionable as only 2 of 15 territory sites yielded blackberries, but differences in English Holly were likely real as 8 of 25 RPS contained English Holly whereas only 1 of 15 TNSs and RTSs $\operatorname{did}$ so $\left(X^{2}=5.88\right.$, df $=2, P=$ 0.053). There was also no difference in the number of each tree species found at the different site type, or the number of quadrants in which each species was the dominant ground cover. In particular, English Ivy was no less common at TNSs that at RPSs or RTSs (Table 2)

\section{Correlation among microhabitat variables and principal component analysis}

Three of 15 correlations among microhabitat variables were statistically significant while three more were marginally significant (Table 3). Not surprisingly, distance from the point to trees was greater when individual trees were large. In addition, density of vegetation at 0.2 and $0.4 \mathrm{~m}$ above ground, and then again between 0.4 and 0.6 to $1.0 \mathrm{~m}$, were positively correlated (Table 3 ).

Results of PCA of the same six vegetation-related variables reported in Table 3 are summarized in Table 4. Principal component 1 (PC1) and PC2 were considered informative because the eigenvalue of both exceeded 1.0, and together they accounted for just over $50 \%$ of the variation in microhabitat structure among sites. PC1 alone accounted for a little over a third 
of the variation, and the negative factor loadings for all variables except horizontal contacts indicted that points with high positive scores were characterized by small, relatively closely packed trees, with few contacts with vegetation above the nest, but more shrub cover (i.e., horizontal contacts. Sites with a negative score had the opposite set of traits. PC2 accounts for $20.3 \%$ of the variation among sites. Sites with a positive value for PC2 contained widely spaced trees, little vegetation above the nest above $0.4 \mathrm{~m}$, and low shrub density. Sites with a negative score would have the opposite traits. Comparisons of PC1 and PC2 among site types were made using ANOVA. Strong differences existed for PC1 $(F=5.44$, df $=2,52, P=0.007)$. TNSs $(-0.515 \pm 0.343)$ and RTS $(-0.562 \pm 0.343)$ did not differ from one another (Tukey’s posthoc test, $P>0.05)$, but both differed from RPSs $(0.646 \pm 0.265$. $)$. Both TNSs and RTSs tended to be found at sites with larger and more widely spaced trees that had little shrubby vegetation but greater ground cover than RPS. For PC2, TNSs $(-0.046 \pm 0.282)$, RTS $(-0.369 \pm 0.282)$ and RPSs $(0.249 \pm 0.219)$ did not differ $(F=1.52, \mathrm{P}=0.229)$.

\section{Discussion}

\section{Factors impacting nest site choice}

Nest predation is the most common cause of nest failure for birds (Martin 1993b). Near-nest vegetation impacts predation rates (Borgman \& Conway 2015), and thus can be a factor in nest failure. In this research, one caveat is that I was only able to find relationships between vegetation and towhee site choice, and not between towhee site choice and nest success. This was mostly due to the fact that there was a limited number of nests available. It is possible that towhees that choose to nest near or away from nonnative vegetation could have differential 
success, but that is out of the scope of this research. In addition, predation rates in this area were somewhat high, so it is quite possible that the most heavily depredated nests located in the worst sites were never found, meaning the sample of nests was not random.

That said, in terms of both size and proximity to the site, trees and shrubs did not seem to have a noticeable direct effect on towhee nesting site choice. Towhees are a ground-nesting species, so this may just indicate that vegetation closer to ground level greatly outweighs any impact that nearby trees would have. However, the PCA indicated that tree size and distance between the nest and nearby trees could impact choice. Both TNS and RTS were more likely to be found in areas with larger and more widely spaced trees, which could be due to indirect effects of shading from large and widely spaced trees that might allow thicker growth of understory herbaceous cover.

Likewise, the species of nearby vegetation did not seem to impact nest site choice. There were no differences found in the amounts of each species found at each site type, nor in the amount of native versus non-native vegetation. It might have been expected that towhees would avoid sites with English ivy, since it could act as an obstacle for young towhees as they leave the nest and begin to forage on the ground. However, in theory, this might be outweighed by the increased protection that nestlings could receive from dense English ivy protecting against predation. Again, since predation rates are so high for this and other ground-nesting species (Solis \& De Lope 1995), protection from nest predation might be so beneficial that it counteracts the risk of obstruction to near-nest ground foraging. In addition, since ivy was extremely common throughout the entire park, it could be that it is too difficult for towhees to find many nest sites in areas that haven't been heavily impacted by English ivy. 
On the other hand, density of vegetation in the area 0.4 to $1.0 \mathrm{~m}$ above the nest did seem to impact towhee nest site choice. Vegetation at $0.4 \mathrm{~m}$ above the nest was strongly correlated with vegetation 0.6 to $1.0 \mathrm{~m}$ above the nest, so vegetation at $0.4 \mathrm{~m}$ above the nest might be the primary range that towhees take into consideration. Above all else, towhees seem to value dense vegetation, possibly as a way of concealing the nest from predators. This would make sense when the relatively high predation rate found in many ground-nesting species is considered (Solis \& De Lope 1995).

Judging by these results, it seems that predation rates are a far more important factor than food availability in terms of towhee nest site choice. Towhees are an omnivorous species, eating a range of foods that includes insects, nuts and berries (Bartos Smith \& Greenlaw 2015). Therefore, while food availability is one factor that influences habitat choice (Connor et al., 1986), it may be that towhees are able to obtain food from a wide enough range of sources that nesting next to one particular food source is less advantageous than nest concealment.

\section{Conservation implications}

Proximity to urban environments is thought to impact birds in a number of ways. Urban birds could potentially experience lower predation rates due to the relative low abundance of typical nest predators, such as snakes, in urban environments (Patten \& Bolger 2003). On the other hand, urban birds could also experience high predation activity from species that are more associated with urban environments, such as domestic cats (Felis catus) (Baker et al. 2008). It can therefore be hard to predict the difficulties birds will face in urban areas. One study by Chamberlain et al. (2009) found that passerines in urban areas tended to lay eggs earlier, have smaller clutch sizes, lower weight nestlings, and less productivity per individual nesting attempt. 
Within these urban environments, factors like habitat structure have been found to impact abundance. For example, Leston \& Rodewald found that the higher relative abundance of Northern cardinals (Cardinalis cardinalis) in urban areas seemed to largely be due to density of understory vegetation (2006). This seems to confirm that for some birds, vegetation density is one of the most critical factors influencing ability to survive urban environments.

In regards to urban towhees specifically, Bartos Smith et al. (2016) found that towhee populations seem to be fairly abundant in urban parks, and are likely self-sustaining. They speculated that towhees may able to produce more young and be relatively successful compared to other ground-nesting birds for a variety of reasons, potentially including omnivorous diet, tendency to use edge habitats, capacity for productivity, and aspects of some urban environments such as low snake abundance. This may help to establish why some ground-nesting birds in urban environments, like the towhee, are more successful than others.

My research helps to show how ground-nesting species like the towhee might respond to factors like an increase in non-native vegetation, changes in vegetation density, and changes in general species composition. While the towhees themselves are considered a species of least concern by the International Union for Conservation of Nature and Natural Resources (“The IUCN Red List of Threatened Species" 2012), other songbird populations are in decline (Askins et al. 1990). Nest predation is one of the leading hypotheses for why these bird populations could be declining (Robinson et al. 1995). Thus, it is important to maintain ground cover and low shrub density for any ground-nesting birds, but especially in urban environments where ground nesting birds tend to be poorly represented (Hedblom \& Söderström 2010).

It seems that ground-nesting birds like the towhee would be much more negatively impacted by management practices that affect the density of vegetation than those that affect the 
species in the area (including amounts of native and non-native vegetation). Removing nonnative shrubs from an area could have negative effects on ground-nesting species that depend on shrubs for protection from predators, at least temporarily. Although some birds might benefit from the removal of nonnative species, ground-nesting species could experience increased nest predation due to a decrease in nest concealment. Restoring native shrubs to an area might be a crucial strategy for protecting these birds from nonnative shrub removal that would impact nest concealment (Donovan \& Flather 2002, Borgmann \& Roldewald 2004).

\section{Acknowledgements}

I thank Dr. Michael Murphy for the tremendous help he gave me throughout this research process. I also thank Molly Shallman and Christine Betlinksi for providing me with the locations of the nest sites.

\section{Literature Cited}

ArcMap (Version 10.4.1) [Computer software]. (2016). Redlands, CA: ESRI.

Askins, R. A., Lynch, J. F., \& Greenberg, R. (1990). Population declines in migratory birds in eastern North America. Current Ornithology 7:57.

Baker, P.J., Molony, S.E., Stone, E., Cuthill, I.C., \& Harris S. (2008) Cats about town: is predation by free-ranging pet cats Felis catus likely to affect urban bird populations? Ibis 150(Suppl. 1):86-99

Bartos Smith, S., \& Greenlaw, J. (2015). Spotted Towhee (Pipilo maculatus), The birds of North America (P. G. Rodewald, Ed.). Ithaca: Cornell Lab of Ornithology; Retrieved from the 
birds of North America: https://birdsna.org/Species-Account/bna/species/spotow DOI: 10.2173/bna.263

Bartos Smith, S., McKay, J. E., Richardson, J. K., \& Murphy, M.T. (2012). Edges, trails, and reproductive performance of Spotted Towhees in urban greenspaces. Studies in Avian Biology 45:167-182

Borgmann, K. L., \& Conway, C. J. (2015). The nest-concealment hypothesis: New insights from a comparative analysis. The Wilson Journal of Ornithology 127:646-660.

Borgmann, K. L., \& Rodewald, A. D. (2004). Nest predation in an urbanizing landscape: the role of exotic shrubs. Ecological Applications 14:1757-1765.

Chamberlain, D. E., Cannon, A. R., Toms, M. P., Leech, D. I., Hatchwell, B. J., \& Gaston, K. J. (2009). Avian productivity in urban landscapes: a review and meta- analysis. Ibis 151:118.

Clark, L., Ricklefs, R. E., \& Schreiber, R. W. (1983). Nest-site selection by the Red-tailed Tropicbird. The Auk: 953-959.

Conner, R. N., Anderson, M. E., \& Dickson, J. G. (1986). Relationships among territory size, habitat, song, and nesting success of Northern Cardinals. The Auk: 23-31.

Donovan, T. M., \& Flather, C. H. (2002). Relationships among North American songbird trends, habitat fragmentation, and landscape occupancy. Ecological Applications 12:364-374.

Haahr, M. (2016). True random number service. Retrieved from https://www.random.org/

Hedblom M., \& Söderström, B. (2010). Landscape effects on birds in urban woodlands: an analysis of 34 Swedish cities. Journal of Biogeography 37:1302-1316.

The IUCN Red List of Threatened Species. (2012). Retrieved from https://www.iucn.org/theme/species/our-work/iucn-red-list-threatened-species 
James, F. C. (1971). Ordinations of habitat relationships among breeding birds. The Wilson Bulletin: 215-236.

Leston, L. F., \& Rodewald, A. D. (2006). Are urban forests ecological traps for understory birds? An examination using Northern cardinals. Biological Conservation 131:566-574.

Lloyd, J. D., \& Martin, T. E. (2005). Reproductive success of Chestnut-collared Longspurs in native and exotic grassland. The Condor 107:363-374.

Martin, T. E., \& Roper, J. J. (1988). Nest predation and nest-site selection of a western population of the Hermit Thrush. The Condor 90:51-57.

Martin, T. E. (1993a). Nest predation among vegetation layers and habitat types: Revising the dogmas. American Naturalist: 897-913.

Martin, T. E. (1993b). Nest predation and nest sites. BioScience 43:523.

Patten, M.A., \& Bolger, D.T. (2003) Variation in top-down control of avian reproductive success across a fragmentation gradient. Oikos 101:479-488

Pleszczynska, W. K. (1978). Microgeographic prediction of polygyny in the Lark Bunting. Science 201:935-937.

Remeš, V. (2003). Effects of exotic habitat on nesting success, territory density, and settlement patterns in the Blackcap (Sylvia atricapilla). Conservation Biology 17:1127-1133.

Ricklefs, R. E. (1969). An analysis of nesting mortality in birds. Smithsonian Institution Press.

Robinson, S. K., Thompson III, F. R., Donovan, T. M., Whitehead, D. R., \& Faaborg, J. (1995). Regional forest fragmentation and the nesting success of migratory birds.

Schill, K. L., \& Yahner, R. H. (2009). Nest-site selection and nest survival of early successional birds in central Pennsylvania. The Wilson Journal of Ornithology 121:476-484. 
Schmidt, K. A., \& Whelan, C. J. (1999). Effects of exotic Lonicera and Rhamnus on songbird nest predation. Conservation Biology 13:1502-1506.

Shipley, A. A., Murphy, M. T., \& Elzinga, A. H. (2013). Residential edges as ecological traps: postfledging survival of a ground-nesting passerine in a forested urban park. The Auk 130:501-511.

Small, S. L. (2005). Mortality factors and predators of Spotted Towhee nests in the Sacramento Valley, California. Journal of Field Ornithology 76:252-258.

Small, S. L., Thompson, F. R., Geupel, G. R., \& Faaborg, J. (2007). Spotted Towhee population dynamics in a riparian restoration context. The Condor 109:721.

Smith, S., McKay, B., Richardson, J., Shipley, E., \& Murphy, J. (2016). Demography of a ground nesting bird in an urban system: Are populations self-sustaining? Urban Ecosystems 19:577-598.

Solis, J. C., \& De Lope, F. (1995). Nest and egg crypsis in the ground-nesting Stone Curlew Burhinus oedicnemus. Journal of Avian Biology: 135-138.

Statistix (Version 9) [Computer software]. (2008). Tallahassee, FL: Analytical Software.

U.S. Census Bureau. (2015, July 1). Retrieved from http://www.census.gov/quickfacts/table/PST045215/4159000,41

Vegetation unit summaries for Lesser Park. (2009, July 29). Retrieved from https://www.portlandoregon.gov/parks/44449?a=278480 
Table 1. Comparison of density and size variables between random sites, nest sites, and random sites near the nest. For statistically significant relationships, sites that share letters do not differ significantly based on posthoc comparisons (Tukey’s test).

\begin{tabular}{ccccc}
\hline \hline & Nest sites $(15)$ & Random territory sites & Random park sites $(25)$ & \\
Variable & Mean $( \pm \mathrm{SD})$ & $(15)$ Mean $( \pm \mathrm{SD})$ & Mean $( \pm \mathrm{SD})$ & $F(P)$ \\
\hline Mean DBH & $1.27(0.086)$ & $1.088(0.086)$ & $1.11(0.066)$ & $1.38(0.262)$ \\
Mean Distance & $3.97(0.305)$ & $3.97(0.305)$ & $3.59(0.236)$ & $0.71(0.497)$ \\
Horizontal Contact & $0.86(0.103)$ & $0.73(0.103)$ & $0.93(0.078)$ & $1.87(0.164)$ \\
Vertical Contact 0.2 & $20.33(2.378)$ & $19.13(2.378)$ & $15.80(1.841)$ & $1.31(0.279)$ \\
Vertical Contact 0.4 & $3.47(0.808) \mathrm{AB}$ & $4.71(0.808) \mathrm{A}$ & $1.12(0.627) \mathrm{B}$ & $6.80(0.002)$ \\
Vertical Contact High & $2.13(0.579) \mathrm{AB}$ & $2.67(0.579) \mathrm{A}$ & $0.80(0.448) \mathrm{B}$ & $3.69(0.032)$ \\
\hline
\end{tabular}


Table 2. Comparison of amount of different vegetation species found among random sites, nest sites, and random territory sites. Horizontal contacts within $2.5 \mathrm{~m}$ of the site are compared, along with number of trees of each species found among the 8 closest trees to the site in NE, NW, SW, and SE direction, as well as number of sections of ground cover in the $5 \mathrm{~m}$ surrounding the nest that were dominated by different species.

\begin{tabular}{lcccc}
\hline \hline \multicolumn{1}{c}{ Variable } & $\begin{array}{c}\text { Nest sites }(15) \\
\text { Mean }( \pm \mathrm{SD})\end{array}$ & $\begin{array}{c}\text { Random sites near nests } \\
(15) \text { Mean }( \pm \mathrm{SD})\end{array}$ & $\begin{array}{c}\text { Other random sites }(25) \\
\text { Mean }( \pm \mathrm{SD})\end{array}$ & $F(\mathrm{P})$ \\
\hline Horizontal contacts & & & & \\
$\quad$ Beaked hazelnut & $4.47(1.467)$ & $4.33(1.467)$ & $5.32(1.136)$ & $0.18(0.835)$ \\
Big leaf maple & $0.20(0.104)$ & $0.00(0.104)$ & $0.00(0.080)$ & $1.35(0.268)$ \\
Douglas fir & $0.00(0.069)$ & $0.13(0.069)$ & $0.00(0.054)$ & $1.35(0.268)$ \\
English hawthorn & $1.53(0.637)$ & $0.53(0.637)$ & $0.72(0.493)$ & $0.73(0.489)$ \\
English holly & $0.27(1.11)$ & $0.33(1.11)$ & $3.12(0.86)$ & $2.94(0.061)$ \\
Himalayan blackberry & $0.73(0.263)$ & $0.07(0.263)$ & $0.00(0.204)$ & $2.66(0.079)$ \\
Thimbleberry & $0.00(1.144)$ & $2.20(1.144)$ & $0.08(0.886)$ & $1.56(0.285)$ \\
Vine maple & $1.27(0.967)$ & $0.06(0.967)$ & $2.32(0.749)$ & $1.71(0.190)$ \\
Trees & & & & \\
Beaked hazelnut & $3.13(0.791)$ & $3.93(0.791)$ & $3.36(0.613)$ & $0.28(0.759)$ \\
Big leaf maple & $3.00(0.687)$ & $2.33(0.687)$ & $2.52(0.532)$ & $0.26(0.775)$ \\
Douglas fir & $1.00(0.226)$ & $0.53(0.226)$ & $0.40(0.175)$ & $2.27(0.114)$ \\
English hawthorn & $0.27(0.149)$ & $0.13(0.149)$ & $0.24(0.115)$ & $0.23(0.792)$ \\
English holly & $0.20(0.232)$ & $0.33(0.232)$ & $0.44(0.180)$ & $0.34(0.715)$ \\
Vine maple & $0.40(0.458)$ & $0.73(0.458)$ & $1.04(0.355)$ & $0.62(0.543)$ \\
Ground cover: & & & & \\
Native species & $1.53(0.432)$ & $2.20(0.432)$ & $1.16(0.335)$ & $1.81(0.173)$ \\
English holly & $0.07(0.285)$ & $0.20(0.285)$ & $0.60(0.221)$ & $1.27(0.288)$ \\
English ivy & $2.93(0.575)$ & $2.40(0.575)$ & $3.16(0.445)$ & $0.55(0.581)$ \\
Himalayan blackberry & $1.40(0.505)$ & $1.13(0.505)$ & $1.08(0.391)$ & $0.13(0.877)$ \\
\hline
\end{tabular}


Table 3. Correlation matrix for the variables of mean distance from the site to nearby trees (Mean Distance), mean DBH of 8 trees near the site (Mean DBH), number of horizontal contacts with vegetation within $2.5 \mathrm{~m}$ of the site (Horizontal Contact), number of contacts with vegetation at $0.2 \mathrm{~m}$ above the site (Vertical Contact 0.2 ), number of contacts with vegetation at $0.4 \mathrm{~m}$ above the site (Vertical Contact 0.4 ), and number of contacts with vegetation at 0.6 to $1 \mathrm{~m}$ above the site (Vertical Contact High).

\begin{tabular}{ccccccc}
\hline \hline & $\begin{array}{c}\text { Mean } \\
\text { Distance }\end{array}$ & $\begin{array}{c}\text { Mean } \\
\text { DBH }\end{array}$ & $\begin{array}{c}\text { Horizontal } \\
\text { Contact }\end{array}$ & $\begin{array}{c}\text { Vertical } \\
\text { Contact 0.2 }\end{array}$ & $\begin{array}{c}\text { Vertical } \\
\text { Contact 0.4 }\end{array}$ & $\begin{array}{c}\text { Vertical } \\
\text { Contact High }\end{array}$ \\
\hline Mean Distance & & & & & & \\
Mean DBH & $0.428^{* *}$ & & & & & \\
Horizontal Contact & $-0.244^{*}$ & $-0.227^{*}$ & & & & \\
Vertical Contact 0.2 & 0.211 & 0.187 & -0.125 & & & \\
Vertical Contact 0.4 & 0.048 & $0.239^{*}$ & $-0.257^{*}$ & $0.343^{* *}$ & & \\
Vertical Contact High & 0.062 & 0.211 & 0.027 & 0.089 & $0.421^{* *}$ & \\
\hline * Marginally significant, $0.1 \geq \mathrm{P} \leq 0.05$ & ** Significant, $\mathrm{P} \leq 0.05$ & & &
\end{tabular}


Table 4. Results of Principal Component Analysis (PCA) for the variables of mean value for distance from the site to nearby trees (Mean Distance), mean DBH of 8 trees near the site (Mean $\mathrm{DBH}$ ), number of horizontal contacts with vegetation within $2.5 \mathrm{~m}$ of the site (Horizontal Contact), number of contacts with vegetation at $0.2 \mathrm{~m}$ above the site (Vertical Contact 0.2 ), number of contacts with vegetation at $0.4 \mathrm{~m}$ above the site (Vertical Contact 0.4 ), and number of contacts with vegetation at 0.6 to $1 \mathrm{~m}$ above the site (Vertical Contact High).

\begin{tabular}{cccccccc}
\hline \hline & & \multicolumn{7}{c}{ Component } \\
\cline { 3 - 7 } & & 1 & 2 & 3 & 4 & 5 & 6 \\
Percent of variance & & 34.2 & 20.3 & 15.5 & 14.1 & 93.2 & 6.8 \\
$\begin{array}{c}\text { Cumulative percent of } \\
\text { variance }\end{array}$ & & 34.2 & 54.4 & 69.9 & 84.0 & 9.1 & 100.0 \\
$\begin{array}{c}\text { Correlation to original } \\
\text { variables }\end{array}$ & & & & & & \\
& & & & & & & \\
& Mean Distance & -0.3961 & 0.5218 & -0.3208 & 0.1931 & 0.5600 & 0.3420 \\
& Mean DBH & -0.4812 & 0.2424 & -0.4186 & -0.0215 & -0.7190 & -0.1305 \\
& Horizontal Contact & 0.3499 & -0.3315 & -0.4852 & 0.6338 & -0.1427 & 0.3319 \\
& Vertical Contact & -0.3902 & -0.0635 & 0.4656 & 0.7167 & 0.0083 & -0.3365 \\
& 0.2 \\
& Vertical Contact & -0.4746 & -0.4626 & 0.2657 & -0.1544 & -0.1107 & 0.6739 \\
& 0.4 & & & & & & \\
& Vertical Contact & -0.3341 & -0.5839 & -0.4461 & -0.1519 & 0.3698 & -0.4342 \\
& High & & & & & &
\end{tabular}

